\title{
OPTIMIZATION OF PHARMACOTHERAPY SYSTEM FOR TREATMENT OF THYROID DISEASES IN UKRAINE
}

\author{
OPTYMALIZACJA SYSTEMU FARMAKOTERAPII \\ W LECZENIU CHORÓB TARCZYCY NA UKRAINIE
}

\author{
Yulia Vadziuk $k^{(A, B, C, D, E, F, G)}$
}

Ternopil State Medical University

Authors' contribution Wkład autorów: A. Study design/planning zaplanowanie badań B. Data collection/entry zebranie danych C. Data analysis/statistics dane - analiza i statystyki D. Data interpretation interpretacja danych

E. Preparation of manuscript przygotowanie artykułu F. Literature analysis/search wyszukiwanie $\mathrm{i}$ analiza literatury G. Funds collection zebranie funduszy
Tables: 1

Figures: 1

References: 10

Submitted: 14.05 .2015

Accepted: 23.12 .2015

\begin{abstract}
Summary
Background. Recent years thyroid diseases are attracting considerable attention. On one hand, this is due to the fact that thyroid is actively reacts on environment, followed by appearance of various diseases. On the other hand, in current conditions population remains face to face with adverse impact of environment because an effective experience of the world community to fight against iodine deficiency is not implemented in Ukraine. Thus every year becomes more patients with thyroid pathology. So there becomes a need to optimize the system of healthcare provision for these patients.

Material and methods. We have analyzed medications listed in Ukrainian National Formulary and studied the dynamics of its formation. A comparative analysis of UNF with the British National Formulary was conducted. The compliance of UNF with the WHO Model List of Essential Medicines was checked.

Results. Comparative analysis of assortment dynamic of UNF medications for treatment and prevention of thyroid diseases showed that foreign drugs had an advantage of inclusion to formulary. The main difference between BNF and UNF is that drugs are brought in BNF only by original name. In UNF antithyroid drugs are presented by thiamazole which is absent in WHO Model List of Essential Medicines and BNF.

Conclusions. We recommend to provide arguments concerning evidence of clinical and cost effectiveness of drugs included to UNF; to include drugs in UNF exclusively by original name; to include carbimazole and propylthiouracil medications into group of antithyroid drugs in UNF; to unite subsections 7.3.2 and 7.3.3 of UNF to one general subsection "antithyroid drugs".
\end{abstract}

Keywords: marketing analysis, pharmacotherapy, thyroid diseases

\section{Streszczenie}

Wprowadzenie. Od jakiegoś czasu choroby tarczycy są obiektem znacznego zainteresowania i uwagi. Jest to z jednej strony spowodowane faktem, że tarczyca aktywnie reaguje na zmiany środowiskowe, w następstwie pojawienia się wielu chorób. Z drugiej strony w obecnych warunkach społeczeństwo staje twarzą w twarz ze szkodliwym wpływ środowiska, ponieważ na Ukrainie nikt nie stosuje się do zasad dyktowanych przez sprawne doświadczenia świata $\mathrm{w}$ walce $\mathrm{z}$ niedoborem jodu. Stąd, co roku odnotowuje się coraz większą liczbę pacjentów z patologicznymi stanami tarczycy. Dlatego też istotna jest potrzeba optymalizacji systemu służby zdrowia dostępnego dla tych pacjentów. Materiał i metody. Przeanalizowaliśmy leki wskazane w Ukraińskim Narodowym Receptariuszu oraz zbadaliśmy dynamike jego utworzenia. Analiza porównawcza UNR z Brytyjskim Narodowym Receptariuszu została przeprowadzona. Sprawdzona została także zgodność tego dokumentu z listą leków podstawowych Światowej Organizacji Zdrowia.

Wyniki. Analiza porównawcza dynamiki asortymentu leków zawartych w UNR w leczeniu i zapobieganiu chorobom tarczycy wykazała, że zagraniczne lekarstwa posiadały zaletę bycia włączonymi do Receptariusza. Podstawową różnicą między BNR a UNR jest fakt, że lekarstwa w ramach BNR są dostępne wyłącznie pod oryginalną nazwą. W UNR lekarstwa przeciwtarczycowe przedstawiane są poprzez tiamazol, który nie występuje na liście leków podstawowych Światowej Organizacji Zdrowia a także BNR.

Podsumowanie. Zalecamy uargumentowanie istnienia dowodów klinicznej i kosztowej efektywności leków włączonych w UNR, włączenie leków w UNR wyłącznie w formie nazwy oryginalnej, włączenie carbimazolu oraz leków na bazie propylotiouracylu do grupy leków przeciwtarczycowych UNR, połączyć podrozdziały 7.3.2 i 7.3.3 UNR w jednej ogólny podrozdział „leków przeciwtarczycowych”.

Słowa kluczowe: analiza marketingowa, farmakoterapia, choroby tarczycy

Vadziuk Y. Optimization of pharmacotherapy system for treatment of thyroid diseases in Ukraine. Health Problems of Civilization 2016 ; $10(1)$ : 10-13. DOI: $10.5114 / \mathrm{hpc} .2016 .58202$

\footnotetext{
Address for correspondence / Adres korespondencyjny: Yulia Vadziuk, Ternopil State Medical University, m.Voli, 1, Ternopil, 46001, e-mail: yuliavadziuk@mail.ru; phone: +38 0979215225

Copyright: ( 2016 Pope John Paul II State School of Higher Education in Biała Podlaska. This is an Open Access journal, all articles are distributed under the terms of the Creative Commons Attribution-NonCommercial-ShareAlike 4.0 International (CC BY-NC-SA 4.0) License (http://creativecommons.org/licenses/by-nc-sa/4.0/), allowing third parties to copy and redistribute the material in any medium or format and to remix, transform, and build upon the material, provided the original work is properly cited and states its license.
} 


\section{Background}

Nowadays significant attention of world's scientists is paid to effectiveness and safety of medicines and optimizing healthcare needs [1]. The implementation of social medical insurance in Ukraine, which the Ministry of Health plans to introduce till the end of 2016 will facilitate this [2]. The main tool to ensure proper prescribing and use of drugs is formulary system.

Formulary system is based on criteria of evidence; it provides cost efficiency, rational prescribing and use of drugs according to established standards. The process of implementation of formulary system can be seen as the optimization of drug therapy in rationalization process of drugs selection in order to increase therapeutic benefits depending on cost of their purchase [3].

It is known that the thyroid disorders are very common, affecting 750 million people worldwide by recent World Health Organization (WHO) estimates, being possibly even more prevalent than diabetes [4,5]. Analysis of official statistical data the Ministry of Health of Ukraine (2009) found a high prevalence of endocrine diseases in Ukraine. According to these criteria endocrine pathology takes one of leading places in the structure of general morbidity. There are a growing number of patients with different endocrinopathies in Ukraine, but the most common among them - thyroid disease (47\% of all diseases of endocrine system) [6].

So we have identified the need for analysis of drugs for treatment of thyroid disease included to the Ukrainian National Formulary (UNF) according to international guidelines.

\section{Material and methods}

We have analyzed medications listed in UNF and studied the dynamics of its formation (2010-2014 years). A comparative analysis of UNF with the British National Formulary (BNF) was conducted. The compliance of UNF with the WHO Model List of Essential Medicines was checked.

\section{Results}

As of January 2015 in Ukraine come out six editions of UNF containing recommendations for prescribing and rational use of drugs considering efficiency, safety and economic feasibility.

We made comparative analysis of assortment dynamic of Formulary medications for treatment and prevention of thyroid disease that were included to the 2nd, 4th and 6th editions of UNF (Figure 1).

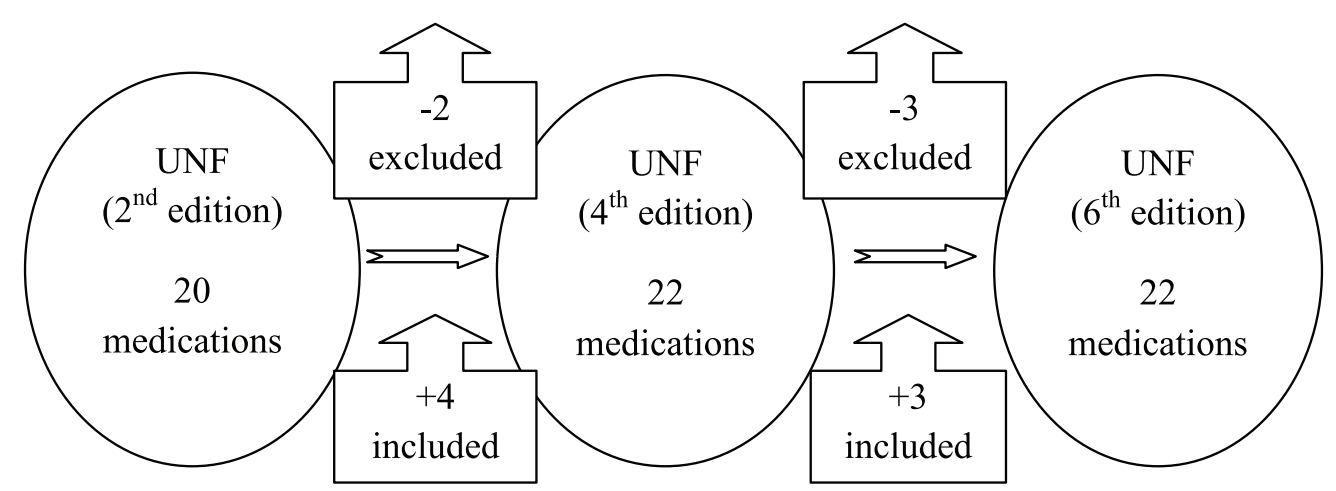

Figure 1. Dynamics of changes in lists of drugs for treatment of thyroid diseases included to different editions of UNF (by their trade names)

As we can see from figure 1, the number of medications of test group included to different editions of UNF is not significantly different. To the fourth edition of UNF 4 new foreign drugs (India, Serbia) were added and 2 domestic drugs were excluded. At inclusion of medications to 6 th edition of UNF there was rotation of three foreign drugs. Inclusion and exclusion of trade names may be associated with expiry of registration certificate or registration of new drugs, because only those drugs that have active registration certificate at the time of viewing are included to Formulary.

WHO considers that $80-90 \%$ of health care needs can provide 700-800 items of drugs. Therefore, the use of high-quality and safe medicines will help reduce morbidity and mortality in many countries. WHO Model List of Essential Medicines has recommendation function and is used as a basis for drafting relevant national lists [7].

We have analyzed presence of medicines for treatment of thyroid diseases included to Ukrainian National Formulary (6th edition) according WHO Model List of Essential Medicines (18th Edition) (Table 1). 
Table 1. The presence of drugs for treatment of thyroid diseases in UNF according to WHO Model List of Essential Medicines

\begin{tabular}{|l|l|l|l|l|}
\hline $\begin{array}{l}\text { WHO Model List of } \\
\text { Essential Medicines }\end{array}$ & $\begin{array}{l}\text { WHO recommended } \\
\text { drug and dosage form }\end{array}$ & $\begin{array}{l}\text { Presence of } \\
\text { drugs in UNF }\end{array}$ & $\begin{array}{l}\text { Presence of WHO } \\
\text { recommended } \\
\text { drug form }\end{array}$ & $\begin{array}{l}\text { Presence of WHO } \\
\text { recommended } \\
\text { dosage form }\end{array}$ \\
\hline Levothyroxine & $\begin{array}{l}\text { Tablet: } 25 \text { micrograms, } 50 \text { micrograms, } \\
100 \text { micrograms }\end{array}$ & + & + & + \\
\hline Potassium iodide & Tablet: $60 \mathrm{mg}$ & + & + & - \\
\hline Propylthiouracil & Tablet: $50 \mathrm{mg}$ & - & - & - \\
\hline
\end{tabular}

As can be seen from table 1, among drugs for treatment of thyroid disease which are present in UNF only medications of levothyroxine are available in recommended drug form and dosage. Completely absent medications of propylthiouracil and potassium iodide drugs have no appropriate dosage form.

On the next stage we analyzed and compared British National Formulary (68th edition) and Ukrainian National Formulary (6th edition).

In UNF drugs for treatment of thyroid diseases are included to Chapter 7 "Endocrinology. Drugs", section 3 "Medicines for treatment of thyroid disease", which contains three subsections: 1 . Thyroid hormones, 2. Antithyroid drugs, 3. Iodine drugs.

Analyzing the BNF we paid attention to the fact that drugs included here only by the original names, unlike UNF, which include both original and generic drugs. Prices of drugs in BNF indicated for full medication package, in UNF the price is calculated by defined daily dose. Drugs for treatment of thyroid diseases are included to Chapter 6 (Endocrinology), section 2 (thyroid and antithyroid drugs), subsections 1. Thyroid hormones, 2. Antithyroid drugs.

According to recommendations of BNF, thyroid hormones include levothyroxine sodium and liothyronine sodium (absent in UNF).

Antithyroid drugs of BNF contain carbimazole, propylthiouracil and iodine. Very importantare recommendations for elimination thyrotoxic crisis, which added to this subsection. Also, the description of use of carbimazole drugs contain warning for doctors regarding caution of use of these medicines because of possibility of side effects (neutropenia, agranulocytosis), and provided detailed action plan for prevention of negative consequences.

\section{Discussion}

Results of comparative analysis of assortment dynamic of Formulary medications for treatment and prevention of thyroid disease that were included to the 2nd, 4th and 6th editions of UNF showed that foreign drugs had an advantage of inclusion to formulary. There is a need to provide arguments concerning evidence of clinical and cost effectiveness of drugs included in UNF, indicating the level of evidence (this is consistent with research results of Panfilova 2009 [8]).

The main difference between British National Formulary and Ukrainian National Formulary is that drugs are brought in BNF only by original name that allows updating formulary twice a year. This approach has sustainable rational foundation, because the certificate of drugs registration have time limits, which means that current principle of formulation of UNF requires constant monitoring of drugs registration and updating on daily basis. Taking into account principle of BNF regulations, validity of medicines registration and inability to update formulary on a constant basis, we consider it necessary to offer optimization of domestic formulary manual in accordance with international practices and to include drugs in Ukrainian National Formulary exclusively by original name.

In UNF antithyroid drugs are presented by thiamazole that is absent in WHO Model List of Essential Medicines and BNF. We consider it necessary to include carbimazole in this group of drugs because its use is accompanied by decrease of side effects and allergic reactions and it will allow patients to continue treatment of diffuse toxic goiter and achieve clinical and immunologic remission. Therapeutic effects of carbimazole and thiamazole are equivalent [9].

We recommend inclusion of propylthiouracil to UNF because it's included to the World Health Organization Model List of Essentian Medicines. It is used only in pregnant women in first trimester and in case of thiamazole intolerance in patients who refuse other treatments [10].

We also suggest unification of subsections 7.3.2 and 7.3.3 of Ukrainian National Formulary to one general subsection "antithyroid drugs" according to British National Formulary and considering presence of only one position (potassium iodide) in subsection 7.3.3. 


\section{Conclusions}

Based on research results, we recommend:

1. To provide arguments concerning evidence of clinical and cost effectiveness of drugs included to UNF, indicating the level of evidence.

2. To include drugs in Ukrainian National Formulary exclusively by original name.

3. To include carbimazole medications into group of antithyroid drugs in UNF.

4. To include propylthiouracil medications into group of antithyroid drugs in UNF.

5. To unite subsections 7.3.2 and 7.3.3 of UNF to one general subsection "antithyroid drugs".

\section{References:}

1. Yevtushenko 0. Pharmacoeconomic evaluation of medicines based of side effects. Journal of Pharmacy. 2010; $1: 51-54$.

2. Boychuk E. Ukrainians answered how much do they pay for drugs. Pharmacist. 2011; 21: 60-61.

3. Barmina A. Formulary system in Ukraine. Pharmacy [cited 2013 Aug 5]; 901(30). Available from: http:// www.apteka.ua/article/224069

4. Gharib H. Emergent Management of Thyroid Disorders. Endocrine and Metabolic Medical Emergencies: A Clinician's Guide. 2014 Jun 11. doi: 10.1210/EME.9781936704811.part4.

5. Zimmerman MB. Iodine deficiency and excess in children: worldwide status in 2013. Endocr Pract. 2013; 19: 839-846.

6. Kravchenko V., Postol S. Dynamics of thyroid morbidity in Ukraine. International Endocrinology Journal. [cited: 2011 Jun 30]; 3(35). Available from: http://www.mif-ua.com/archive/article/17759

7. Zaliska O. Pharmacoeconomics. Lviv: Affiche; 2007.

8. Panfilova A. Substantiation of organization-economic recommendations on creation of Ukrainian Formulary Guidance of drugs. Management, Economy and Quality Assurance in Pharmacy. 2009; 1(3): 58-63.

9. Pankiv V. Thyreostatic medicines in therapy of diffuse toxic goiter. International Endocrinology Journal. 2013; 3(51): 10-16.

10. Bahn R, Burch H, Cooper D, Garber J, Greenlee M, Klein I, et al. Hyperthyroidism and other causes of thyrotoxicosis: management guidelines of the American Thyroid Association and American Association of clinical endocrinologists. Endocrine practice. 2011;17(3):65. 